
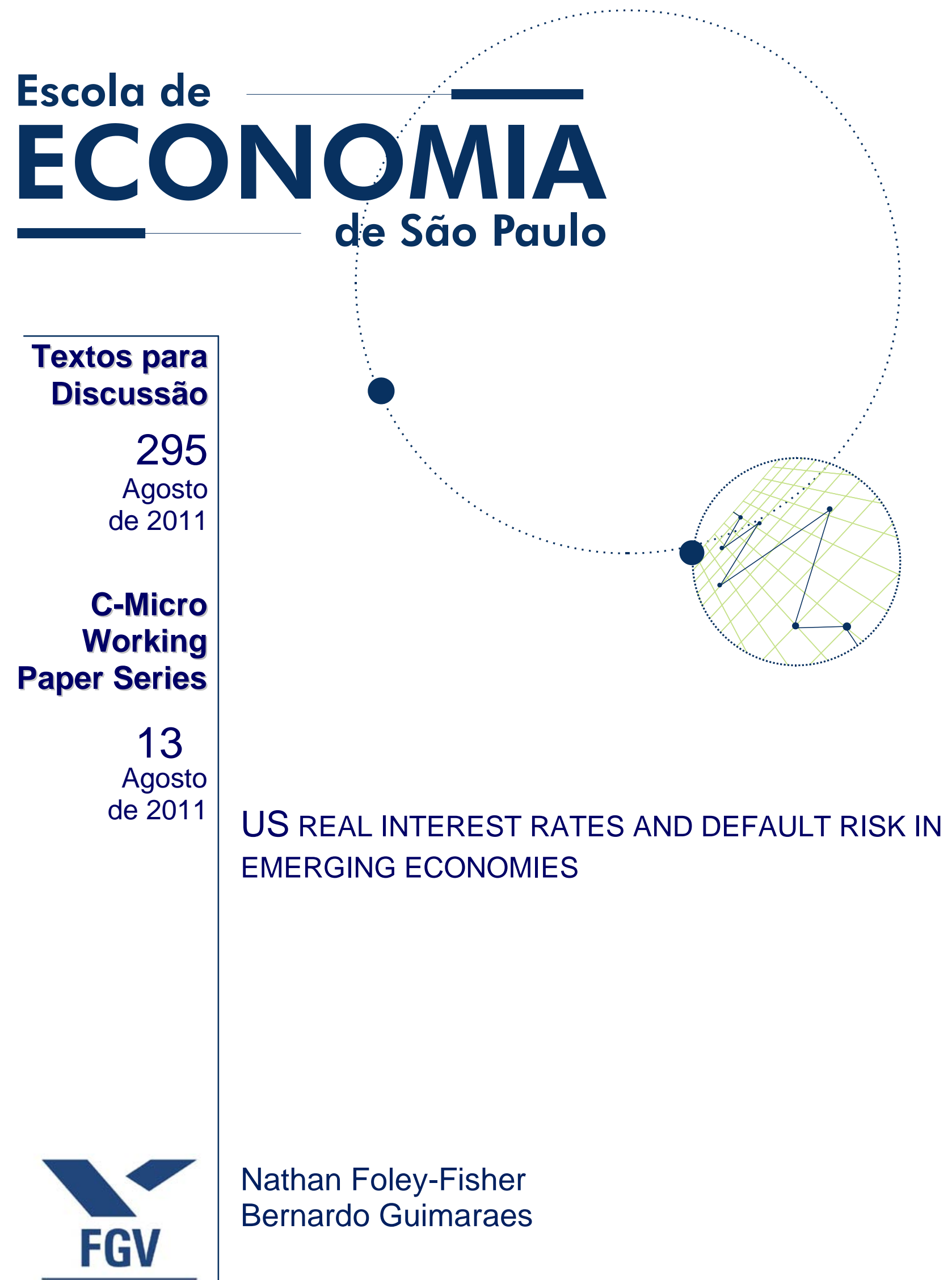

Nathan Foley-Fisher

Bernardo Guimaraes 
Os artigos dos Textos para Discussão da Escola de Economia de São Paulo da Fundação Getulio Vargas são de inteira responsabilidade dos autores e não refletem necessariamente a opinião da FGV-EESP. É permitida a reprodução total ou parcial dos artigos, desde que creditada a fonte.

Escola de Economia de São Paulo da Fundação Getulio Vargas FGV-EESP www.eesp.fgv.br 


\title{
US real interest rates and default risk in emerging economies
}

\author{
Nathan Foley-Fisher* $\quad$ Bernardo Guimaraes ${ }^{\dagger}$
}

March 2011

\begin{abstract}
This paper empirically investigates the impact of changes in US real interest rates on sovereign default risk in emerging economies using the method of identification through heteroskedasticity. Policy-induced increases in US interest rates starkly raise default risk in emerging market economies. However, the overall correlation between US real interest rates and the risk of default is negative, demonstrating that the effects of other variables dominate the anterior relationship.
\end{abstract}

KEYWORDS: real interest rates; default risk; sovereign debt; identification through heteroskedasticity.

JEL Classification: F34, G15

\section{Introduction}

The theoretical economic effect of changes in US real interest rates on default risk in emerging economies has been studied by, amongst others, Neumeyer and Perri (2005) and Guimaraes (2011). In straightforward terms, the mechanism runs that when US real interest rates rise, the opportunity costs to those who buy emerging economies' debt increase, and emerging economies react by offering a similar higher interest rate. This direct effect increases the debt burden on emerging economies, raising the risk they will default on their debt and requiring emerging economies offer even higher interest rates in compensation. Anecdotal evidence from the Latin American debt crisis of the 1980's and the Mexican crisis in 1994, both of which were preceded by sharp interest rate hikes in the US, suggests this theoretical channel might be an important empirical one.

Empirically identifying this theoretical relationship is not trivial, however, owing to the usual endogeneity problems of reverse causality and common omitted variables. The

${ }^{*}$ n.foley-fisher@lse.ac.uk, Department of Economics and STICERD, London School of Economics

†bernardo.guimaraes@fgv.br, Sao Paulo School of Economics - FGV 
latter is especially problematic because US real interest rates and default risk in emerging economies are both affected by variables that cannot be easily measured, such as global market factors, risk premia, and expectations about economic performance and the political scenario.

This paper identifies the effects of changes in US real interest rates on default risk in emerging economies using the method of identification through heteroskedasticity as set out by Rigobon (2003) and Rigobon and Sack (2004). As discussed in detail in Section 2, we take data on US real interest rates from inflation-indexed Treasury bonds, and proxy default risk using J.P. Morgan's Emerging Markets Bond Index Plus (EMBI+) premia in emerging economies over the period between 1998 and 2008. The idea behind the identification method is simply that there is a greater variance of changes in real interest rates on dates when the Federal Open Market Committee (FOMC) meets. The meetings of the FOMC can be seen as an extra shock to US interest rates, which impact on the EMBI+ premia.

The key identifying assumption is that there are no other systematic shocks to EMBI+ premia on dates where the FOMC meets. We are assuming that the timing of FOMC meetings do not affect the EMBI+ premia through any channel other than the changes in real interest rates. This assumption resembles the desired characteristics of an instrument in IV regressions. The main difference is that here we do not have a novel instrumental variable, the estimators are based on differences in the covariance matrices of our data between dates when the FOMC does and does not meet.

Our findings are presented in Section 3, where we show that unexpected policyinduced increases in interest rates lead to much greater EMBI+ premia and, by implication, default risk in emerging economies. A 1 basis-point increase in 10-year US real interest rates raises EMBI+ premia by around 1 basis point, which means that the cost of borrowing in emerging economies rises substantially more than in the US. This confirms the hypothesised theoretical relationship between changes in US real interest rates and the risk of default, and suggests that more attention ought to be paid to this relationship in the literature on default risk.

One particular policy implication of this theoretical relationship is that emerging economies should issue debt contingent on US real interest rates, because such a contingency would negate the increased default risk not associated with fundamental changes in emerging economies. However the usefulness of this policy depends not on the causal relationship between US real interest rates and the EMBI+ premium, but on the correlation between both. Omitted variables that significantly affect this correlation would also 
affect the performance of debt contracts contingent on US real interest rates.

In actuality, on dates when the FOMC does not meet, we observe a significant correlation with the opposite sign: changes in real interest rates are negatively related to changes in EMBI+ premia. Moreover, the overall correlation between real interest rates and the EMBI+ premium is negative: a 2 bp increase in the 10-year US real rate is on average related to a $1 \mathrm{bp}$ decrease in the EMBI+. The results suggest that high real interest rates reflect favourable external conditions for emerging markets, which reduce the risk of default. This finding resonates with that of Longstaff et al. (2007), where global risk factors (proxied by US markets) are shown to be the major determinant of sovereign credit risk premia. Regardless of the precise reason for the negative correlation, the policy implication is clear: emerging economies should not issue debt contingent on US real interest rates.

Previous academic work has attempted to establish the nature of the relationship between US real interest rates and sovereign default risk by applying different methods to deal with the aforementioned endogeneity problems. Some of this work has relied on structural assumptions in vector autoregressions to identify the relationship (e.g., Uribe and Yue (2006)). For our purposes, high-frequency data on financial prices can provide more information and allow for a cleaner identification strategy ${ }^{1}$.

An alternative to structural assumptions are 'traditional' instruments in IV strategies, such as in Zettelmeyer (2004) where changes in the policy rate are employed as instruments for longer-term real interest rates. This methodology also needs to assume that changes in the instrument do not affect EMBI+ premia through alternative channels. Moreover, the instruments themselves must be exogenous, which is a stronger, and therefore less desirable, assumption than that employed in this paper.

Additional studies investigate the direct effect of changes in the US federal funds target rate on emerging market spreads (Arora and Cerisola, 2001). However, the theoretical relationship of interest is between default risk and the longer-term real interest rate, not the short-term nominal rate, which cannot be assumed to be endogenous. Moreover, even changes in the target rate might not be exogenous (see Rigobon and Sack (2004)).

\section{Data and empirical methodology}

We use the following data to investigate the relationship between US real interest rates and the risk of default. Our measure of the interest rate, $i$, is from 10-year inflationindexed Treasury bonds. To quantify the risk of default, e, we use J.P. Morgan's Emerging

\footnotetext{
${ }^{1}$ Uribe and Yue (2006) also study the effect of interest rates and the EMBI+ premium on variables like output, and in that case our methodology cannot be applied.
} 
Markets Bond Index Plus (EMBI+), which is comprised of medium-term debt of more than one year to maturity ${ }^{2}$. All data are obtained from the Global Financial Database (www.globalfinancialdata.com).

We want to obtain long data series with minimal concern for events that might obfuscate a potential relationship. For this reason we select emerging economies that have not defaulted and use daily data running from January 1998 to December 2008. We are interested in how a change in the interest rate changes the EMBI+ premia, so our sample consists of values of $\Delta e_{t}=e_{t+1}-e_{t-1}$ and $\Delta i_{t}=i_{t+1}-i_{t-1}$, and is divided in two: the sub-sample $C$ corresponds to the dates of monetary policy shocks, and the sub-sample $N$ corresponds to dates with no shocks. ${ }^{3}$

There are two endogeneity concerns that mean a simple ordinary least squares regression will not identify the effect of changes in US real interest rates on the risk of default $(\mathrm{EMBI}+$ premia). First, changes in the EMBI+ premia can cause changes in the interest rate, for example, when default risk falls and in response investors switch demand from safe Treasury assets to emerging market debt. Second, and more importantly, the interest rate and the exchange rate are influenced by other common omitted variables. The following system of equations is a simple representation of both endogeneity issues:

$$
\begin{aligned}
\Delta e_{t} & =\alpha \Delta i_{t}+z_{t}+\eta_{t} \\
\Delta i_{t} & =\beta \Delta e_{t}+\gamma z_{t}+\varepsilon_{t}
\end{aligned}
$$

Where $\Delta i_{t}$ is the change in US real interest rate; $\Delta e_{t}$ the change in the EMBI+ premium; $z_{t}$ a vector of omitted variables including, for example, external market conditions; $\varepsilon_{t}$ a monetary policy shock; and $\eta_{t}$ a shock to EMBI+.

The objective is to identify $\alpha$ in Equation 1. Our identification strategy is borrowed from Rigobon and Sack (2004), who show that the impact of monetary policy shocks on asset prices can be identified because the variance of shocks is substantially larger on the days in sub-sample $C$. Their paper used the identification strategy to establish a significant response of 10-year Treasury yields to monetary policy shocks.

That monetary policy shocks can influence 10-year real interest rates means the variance of changes in these rates is significantly larger on the days in sub-sample $C$. This effect is not large, but is large enough to significantly affect the variance of $\Delta i_{t}$. We exploit

\footnotetext{
${ }^{2}$ EMBI+ tracks total returns for traded US dollar- and other external currency-denominated Brady bonds, loans, Eurobonds and local market instruments.

${ }^{3}$ Set $\mathrm{C}$ contains the dates of scheduled and unscheduled FOMC meetings and the Federal Reserve Chairman's semi-annual monetary policy testimony to Congress. For a full list of these dates, see http://www.federalreserve.gov/monetarypolicy/fomccalendars.htm
} 
this effect by combining it with the assumption that the policy shock to real interest rates neither affects EMBI+ through $z_{t}$ nor $\eta_{t}$, but only through its effect on $\Delta i$.

In sum, we assume that the variance of interest rate shocks $\left(\varepsilon_{t}\right)$ in sub-sample $C$ is higher than the variance in sub-sample $N$; whilst the variances of $\eta_{t}$ and $z_{t}$ are the same across both sub-samples. As is usual in other identification strategies for our underlying system of equations, we assume $z_{t}, \varepsilon_{t}$ and $\eta_{t}$ have no serial correlation and are uncorrelated with each other. Our assumptions can be written in terms of the second moments of the shocks in the two sub-samples $C$ and $N$ in the following way:

$$
\begin{aligned}
\sigma_{\varepsilon}^{C} & >\sigma_{\varepsilon}^{N} \\
\sigma_{\eta}^{C} & =\sigma_{\eta}^{N} \\
\sigma_{z}^{C} & =\sigma_{z}^{N}
\end{aligned}
$$

To help justify the underlying assumptions, we established that the standard deviation of the real interest rate increases significantly in sub-sample $C$, while the variance of EMBI+ does not significantly change, because the effect of the variance increase in Equation 2 only weakly effects the variance of EMBI+ through the interest rate. The results from formally testing the change of variances across sub-samples are in the appendix.

We are not assuming that the FOMC ignores factors that affect emerging market default risk. But we are assuming that FOMC decisions do not directly reveal important information about emerging markets that might otherwise affect EMBI+ premia, they are only affecting EMBI+ premia through changes in US real interest rates - which is the usual assumption in IV regressions. The difference here is that instead of having a variable assumed to be correlated with $\varepsilon$ and uncorrelated with any of the other variables, we assume that the variance of $\varepsilon$ is larger on the days in sub-sample $\mathrm{C}$, and the variances of other variables are the same in both sub-samples.

Now, consider the following variables:

$$
\begin{aligned}
\Delta I & \equiv\left[\frac{\Delta i_{C}^{\prime}}{\sqrt{T_{C}}}, \frac{\Delta i_{N}^{\prime}}{\sqrt{T_{N}}}\right]^{\prime} \\
\Delta E & \equiv\left[\frac{\Delta e_{C}^{\prime}}{\sqrt{T_{C}}}, \frac{\Delta e_{N}^{\prime}}{\sqrt{T_{N}}}\right]^{\prime} \\
w & \equiv\left[\frac{\Delta i_{C}^{\prime}}{\sqrt{T_{C}}}, \frac{-\Delta i_{N}^{\prime}}{\sqrt{T_{N}}}\right]^{\prime}
\end{aligned}
$$

A major result in Rigobon and Sack (2004) is that $\alpha$ can be consistently estimated 
by a standard instrumental variables approach with the novel instrument, $w$, which is correlated with the dependent variable, $\Delta I$, but is neither correlated with $z_{t}$ nor $\eta_{t}$. It's correlated with $\Delta I$ because the greater variance in sub-sample $C$ implies the positive correlation between $\left(\Delta i_{C}^{\prime} / \sqrt{T_{C}}\right)$ and $\left(\Delta i_{C}^{\prime} / \sqrt{T_{C}}\right)$ more than outweighs the negative correlation between $\left(\Delta i_{N}^{\prime} / \sqrt{T_{N}}\right)$ and $\left(-\Delta i_{N}^{\prime} / \sqrt{T_{N}}\right)$. It's neither correlated with $z_{t}$ nor $\eta_{t}$ because the positive and negative correlation of each part of the vector cancel each other out.

\section{Results}

Table 1 presents the results from implementing our identification strategy, which reveals that policy shocks to real interest rates are positively correlated with emerging economies' EMBI+. This coincides with our original intuition that when the US government tightens monetary policy, it is harder for emerging economies to borrow, and the risk of default proxied by EMBI+ increases.

Table 1: The response of EMBI+ premia to interest rate shocks

\begin{tabular}{l|ccc}
\hline & Co-eff & Std Err & T-stat \\
\hline \hline Emerging Market & 0.868 & 0.179 & 4.840 \\
Latin America & 1.115 & 0.195 & 5.717 \\
\hline Brazil & 1.334 & 0.269 & 4.969 \\
Bulgaria & 0.649 & 0.170 & 3.808 \\
Mexico & 0.607 & 0.138 & 4.394 \\
Panama & 0.496 & 0.094 & 5.264 \\
Peru & 0.659 & 0.140 & 4.697 \\
Venezuela & 2.279 & 0.318 & 7.162 \\
\hline Each estimation uses 2,735 observations.
\end{tabular}

The magnitude of the response is large: an unexpected increase in the 10-year real interest rate of one basis point leads to an increase in the EMBI+ premium of a similar order of magnitude.

Table 3 shows the results from analysis of the relationship between US real interest rates and EMBI+ premia in each separate sub-sample of the data (the results across both samples are in table 2). Crucially, the 'normal' correlation between $\Delta E$ and $\Delta I$ is actually negative (and smaller in absolute value) in sub-sample $N$. Our interpretation is that increases in US real interest rates are correlated with other things that are good for emerging markets and thus decrease their cost of borrowing. Future research ought to investigate which aspects of international financial markets, correlated with US real interest rates, are most important to the risk of emerging market default. 
Table 2: Full sample analysis

\begin{tabular}{l|ccc}
\hline & Co-eff & Std Err & T-stat \\
\hline \hline Emerging Market & -0.423 & 0.082 & -5.174 \\
Latin America & -0.503 & 0.091 & -5.535 \\
\hline Brazil & -0.547 & 0.135 & -4.038 \\
Bulgaria & -0.226 & 0.077 & -2.934 \\
Mexico & -0.443 & 0.062 & -7.194 \\
Panama & -0.437 & 0.041 & -10.586 \\
Peru & -0.375 & 0.059 & -6.347 \\
Venezuela & -0.467 & 0.143 & -3.266 \\
\hline
\end{tabular}

Each estimation uses 2,735 observations.

Table 3: Separate analysis of sub-samples

\begin{tabular}{l|ccc|ccc}
\multicolumn{1}{c}{} & \multicolumn{3}{c}{ Set C } & \multicolumn{3}{c}{ Set N } \\
\cline { 2 - 7 } & Coeff & Std Err & T-Stat & Coeff & Std Err & T-stat \\
\hline \hline Emerging Market & 0.230 & 0.224 & 1.029 & -0.494 & 0.087 & -5.700 \\
Latin America & 0.317 & 0.228 & 1.390 & -0.591 & 0.096 & -6.131 \\
\hline Brazil & 0.406 & 0.275 & 1.474 & -0.649 & 0.145 & -4.492 \\
Bulgaria & 0.217 & 0.226 & 0.960 & -0.274 & 0.081 & -3.363 \\
Mexico & 0.089 & 0.177 & 0.503 & -0.500 & 0.065 & -7.692 \\
Panama & 0.036 & 0.114 & 0.311 & -0.487 & 0.044 & -11.186 \\
Peru & 0.146 & 0.191 & 0.766 & -0.430 & 0.062 & -6.937 \\
Venezuela & 0.924 & 0.389 & 2.371 & -0.617 & 0.151 & -4.076 \\
\hline
\end{tabular}

131 observations in Set C, 2,604 days in Set N.

The results in table 1 are substantially different from the OLS estimates using only the Set $\mathrm{C}$ presented in table 3 . While the former shows a strong positive relation, the latter shows a mild and insignificant effect. Rosa (2011) has noted that, in some applications, the results from employing the identification through heteroskedasticity methodology are not much different from a simple OLS using the subsample where the FOMC meets. That is not the case here since we are using the long-term interest rates, where endogeneity is likely to be much more important than when the policy rate is used, and the correlation between variables in the $\mathrm{N}$ sample is very different from the causal effect.

\section{Concluding remarks}

The strong and positive relation between exogenous changes in US real interest rates and the EMBI+ premium highlight the importance of US interest rate shocks. The fact that the overall correlation between US rates and the EMBI+ premium is negative stresses the importance of other aspects of international financial markets, such as favourable external 
conditions to emerging economy borrowing. From a policy perspective, this result tell us that making emerging market sovereign debt contingent on US real interest rates is not a good idea. Research on sovereign default should note that shocks affecting foreign real interest rates might have very different effects on emerging market default risk.

\section{References}

Arora, V. and Cerisola, M. (2001). How Does U.S. Monetary Policy Influence Sovereign Spreads in Emerging Markets?, IMF Staff Papers 48: 474-498.

Guimaraes, B. (2011). Sovereign default: which shocks matter?, Review of Economic Dynamics . forthcoming.

Levene, H. (1960). Robust tests for equality of variances, in I. O. et al. (ed.), In Contributions to Probability and Statistics: Essays in Honor of Harold Hotelling, Stanford University Press, pp. 278-292.

Longstaff, F., Pan, J., Pedersen, L. and Singleton, K. (2007). How Sovereign is Sovereign Credit Risk?, NBER Working Paper No. 13658.

Neumeyer, P. and Perri, F. (2005). Business cycles in emerging economies: the role of interest rates, Journal of Monetary Economics 52(2): 345-380.

Rigobon, R. (2003). Identification through heteroskedasticity, Review of Economics and Statistics 85(4): 777-792.

Rigobon, R. and Sack, B. (2004). The impact of monetary policy on asset prices, Journal of Monetary Economics 51(8): 1553-1575.

Rosa, C. (2011). The validity of the Event-Study Approach: Evidence from the Impact of the Fed's Monetary Policy on U.S. and Foreign Asset Prices, Economica . forthcoming.

Uribe, M. and Yue, V. (2006). Country spreads and emerging countries: Who drives whom?, Journal of International Economics 69(1): 6-36.

Zettelmeyer, J. (2004). The impact of monetary policy on exchange rates: evidence from three small open economies, Journal of Monetary Economics 51(3): 635-652. 


\section{A Appendix}

Table 4 presents some descriptive statistics on changes in the 10-year real interest rate and EMBI+ premia for sub-samples $C$ and $N$.

Table 4: Data descriptives

\begin{tabular}{l|cc|cc}
\hline & \multicolumn{2}{|c|}{ Standard deviation } & \multicolumn{2}{c}{ Covariance with US real rate } \\
\cline { 2 - 5 } & Set C & Set N & Set C & Set N \\
\hline \hline US real rate & 0.093 & 0.063 &. & - \\
Emerging Market & 24.491 & 29.020 & 0.198 & -0.211 \\
Latin America & 25.017 & 32.317 & 0.278 & -0.253 \\
\hline Brazil & 30.249 & 48.318 & 0.357 & -0.278 \\
Bulgaria & 24.476 & 27.181 & 0.175 & -0.117 \\
Mexico & 19.221 & 21.876 & 0.066 & -0.214 \\
Panama & 12.486 & 14.849 & 0.028 & -0.208 \\
Peru & 20.892 & 20.939 & 0.128 & -0.185 \\
Venezuela & 43.545 & 50.526 & 0.852 & -0.263 \\
\hline
\end{tabular}

131 observations in Set C, 2,604 days in Set N.

The increase in the variation in the US real interest rate and the change in covariance between the real interest rate and EMBI+ premia over the sub-samples are apparent from the table, but the fact that standard deviation of EMBI+ appears to decrease from set $N$ to set $C$, when we expect it to mildly increase, suggests we require a more accurate statistical test of whether our assumptions on the variance of shocks over the two subsamples are valid.

Importantly, however, we cannot apply standard tests of variance equality, because they require that the underlying data be normally distributed. As the plots of each variables' quantiles against those of the normal distribution in Figure 1 demonstrate, and the empirical tests of skewness and kurtosis confirm in Table 5, none of our series are normally distributed.

Levene (1960) provides a test where the null is equal variance when samples are drawn from a distribution that is not Gaussian normal. The results from this test are presented in Table 6, and show that the variance of the US real interest rate significantly increases, but the variance of all EMBI+ premia does not change significantly. ${ }^{4}$

On the basis of these results, we conclude that the standard deviation of the real interest rate increases significantly on the days when the variance of interest rate movements is greater. We cannot reject the null that the variance of EMBI+ is the same in

\footnotetext{
${ }^{4}$ The results are presented using the sample mean of the data, similar results are obtained when using the 50 th percentile or $10 \%$ trimmed mean
} 
Figure 1: Q-Q plots of each variable quantiles against normal distribution quantiles
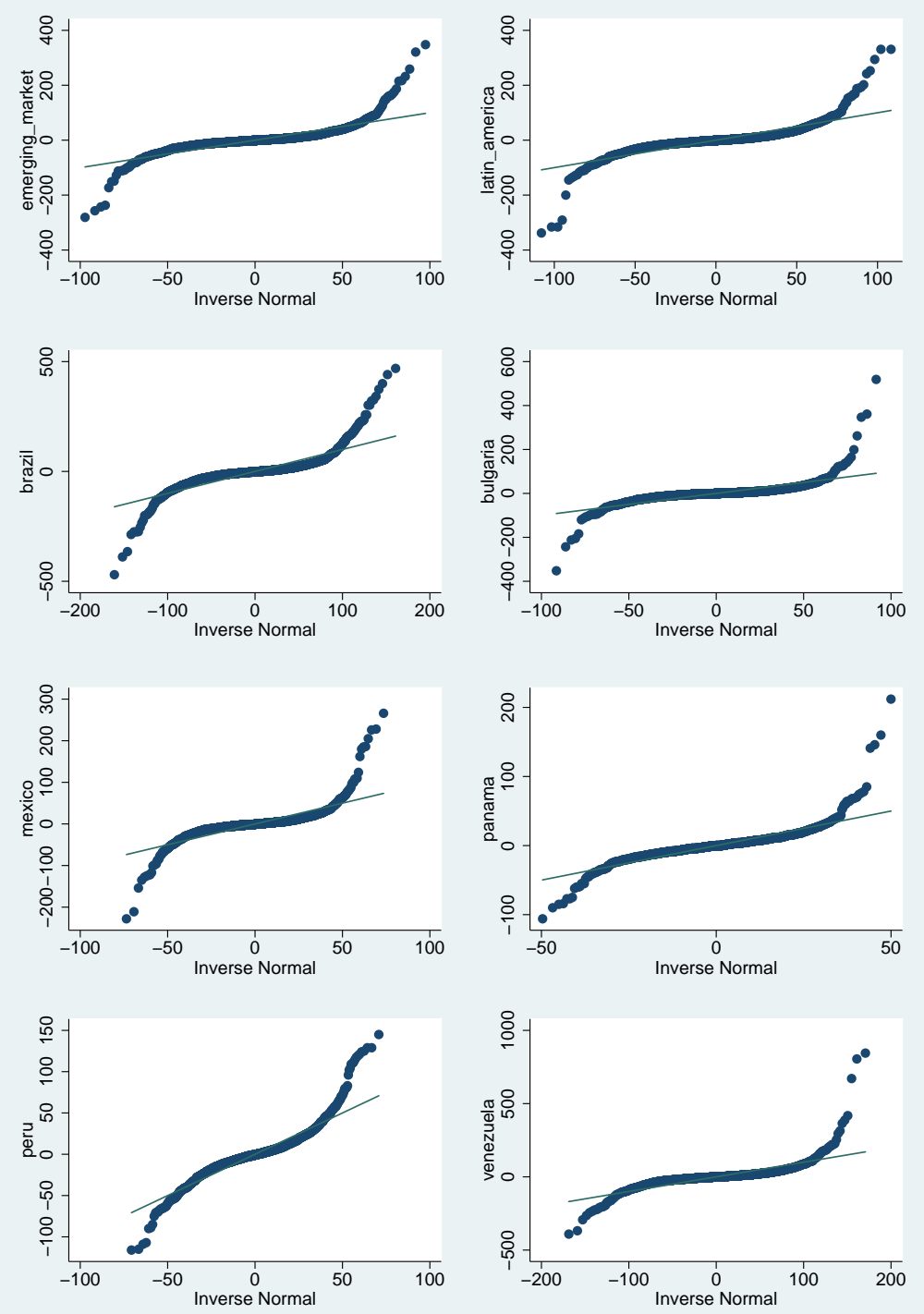
Table 5: Test of skewness and kurtosis

\begin{tabular}{l|cc}
\hline & $\begin{array}{c}\text { skewness } \\
\text { p-value }\end{array}$ & $\begin{array}{c}\text { kurtosis } \\
\text { p-value }\end{array}$ \\
\hline \hline US real rate & 0.000 & 0.000 \\
Emerging Market & 0.000 & 0.000 \\
Latin America & 0.000 & 0.000 \\
\hline Brazil & 0.000 & 0.000 \\
Bulgaria & 0.000 & 0.000 \\
Mexico & 0.000 & 0.000 \\
Panama & 0.000 & 0.000 \\
Peru & 0.000 & 0.000 \\
Venezuela & 0.000 & 0.000 \\
\hline
\end{tabular}

Null hypothesis is normal distribution

Table 6: Levene (1960) test of equal variance

\begin{tabular}{l|cc}
\hline & $\begin{array}{c}\text { Test statistic } \\
\text { based on mean }\end{array}$ & p-value \\
\hline \hline US real rate & 12.371 & 0.000 \\
Emerging Market & 0.215 & 0.643 \\
Latin America & 0.458 & 0.499 \\
\hline Brazil & 2.273 & 0.132 \\
Bulgaria & 0.000 & 0.977 \\
Mexico & 0.031 & 0.860 \\
Panama & 0.021 & 0.884 \\
Peru & 0.908 & 0.341 \\
Venezuela & 0.635 & 0.801 \\
\hline
\end{tabular}

Null hypothesis is equal variance

both sub-samples. According to our assumptions, the policy shocks should yield only small increases in the variance of EMBI+, as the unexpected policy shocks to US real interest rates are only a small part of the variation of emerging market default risk, so the results of the tests on variances in both sub-samples, albeit not conclusive, are not at odds with the identifying assumptions. 